\title{
SCIDiC
}

International Journal of Dentistry and Oral Science (IJDOS)

ISSN: 2377-8075

\section{Alveoloplasty in Complete Denture Patients - A Retrospective Study}

Research Article

Amanthi Ganapathi ${ }^{1}$, Dhanraj Ganapathy ${ }^{2 *}$, M. Jeevitha ${ }^{3}$

${ }^{1}$ Saveetha Dental College and Hospital, Saveetha Institute of Medical and Technical Sciences, Saveetha University, Chennai 600077, Tamil Nadu, India.

${ }^{2}$ Professor and Head, Department of Prosthodontics, Saveetha Dental College and Hospital, Saveetha Institute of Medical and Technical Sciences,

Saveetha University, Chennai 600077, Tamil Nadu, India.

${ }^{3}$ Senior lecturer, Department of Periodontics, Saveetha Dental College and Hospital, Saveetha Institute of Medical and Technical Sciences, Saveetha University, Chennai 600077, Tamil Nadu, India.

\section{Abstract}

Preprosthetic surgery is an integral part of complete denture prosthodontics. The ultimate goal of pre prosthetic surgery is to prepare a mouth to receive dental prosthesis by redesigning and smoothening bony edges which would otherwise cause hindrance in restoration of optimum health and function. This study was done to determine the prevalence of alveoloplasty done among complete denture patients. It is hospital based study, were patients case sheet were reviewed and analysed from the time period of june 2019-march 2020 at saveetha dental college and hospitals. A total of 86,000 were reviewed out of which 393 patients were complete denture patients. Incidence of alveoloplasty was analysed using SPSS software.

In our present study a total of 393 patients' case sheets were reviewed out of which only 39 patients had undergone alveoloplasty, whereas 351 patients did not undergo any type of pre-prosthetic surgery. $9.92 \%$ of completely edentulous patients have undergone alveoloplasty. $5.1 \%$ of the males and $4.85 \%$ of the female completely edentulous patients underwent alveoloplasty, however, no statistically significant differences between both the groups were observed.(Pearson Chi square test; $\mathrm{P}=0.416$, $\mathrm{P}>0.05$ ). With the limitation of our study, patients who underwent alveoloplasty before receiving complete denture were found to be minimal. Alveoloplasty should be mandated in suitable situations to ensure better health of complete denture patients and eventually to improve comfort and success rate.

Keywords: Complete Denture; Pre-Prosthetic Surgery; Alveoloplasty; Hard Tissue; Denture Bearing Area.

\section{Introduction}

Preprosthetic surgery is an integral part of complete denture prosthodontic surgery is done to provide a better anatomic environment and to create a proper supporting structure of denture constitution [44]. Lawson raised a question: "Why should it be assumed that full denture is the one type of dental restoration for which the mouth is already perfectly designed" [24]. Most of the time significant enhancement can often be achieved by surgical preparation before denture construction. The main function of preprosthetic surgery are to eliminate the pathology in the denture bearing soft and hard tissues of the denture base and ridge improvement [16, 19, 21].
Objective of pre prosthodontic procedure is Correcting conditions that preclude optimal prosthetic function [10]. Hyperplastic replacement of resorbed ridges, unfavourable located frenulum attachments, bony prominences and undercuts should be corrected before complete denture treatment.

Alveoloplasty is one of the most common pre-prosthodontic surgical procedures done in dental practice. The aim of the prosthetic surgery is to improve the quality and condition of the hard and soft tissues of the oral supporting structures. So, that they have better retention, stability and support to the dental prosthesis [4, 41]. The bony prominences are removed by means of alveoloplasty and alveolectomy. "Alveoloplasty" is the term used to describe the trimming and removal of the labial buccal alveolar long

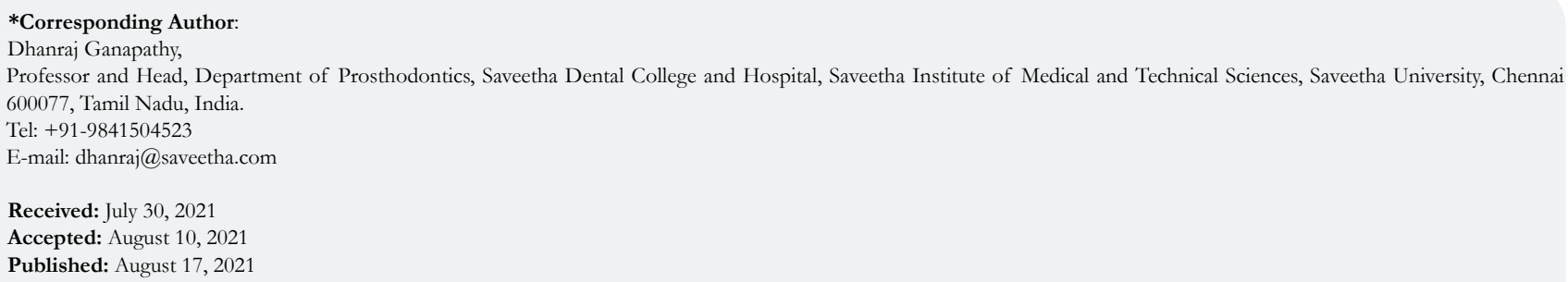

Copyright: Dhanraj Ganapathy ${ }^{\circ} 2021$. This is an open-access article distributed under the terms of the Creative Commons Attribution License, which permits unrestricted use, distribution and reproduction in any medium, provided the original author and source are credited. 
along with some internal and interradicular bone and is carried out at the time of extraction and after the extraction of the teeth. When surgery is planned on edentulous ridge, incision should be made on the crest of the alveolar ridge; usually the envelope flap would suffice, but releasing incision can be made on the labial side to provide a broad base to the flap, $[14,43]$.

Edentulism is the condition of being toothless. Fall/removal of some teeth results in partial edentulism, whereas loss of all the teeth results in complete edentulism. Edentulism can affect the functional and sensory disturbances to the oral mucosa and salivary gland eddentulous patients are liable to reduce the tissue reformation and reduce tissue concentration that affects the protective function of the oral mucosa $[25,47]$

Previously our team has a rich experience in working on various research projects across multiple disciplines. (Jain, 2017 [18]); (Varghese, Ramesh and Veeraiyan, 2019 [45]); (Ashok and Ganapathy, 2019 [2]); (Padavala and Sukumaran, 2018 [29]); (Ke et al., 2019 [22]); (Ezhilarasan, 2018 [11]); (Krishnan et al., 2018 [23]); (Ezhilarasan, Sokal and Najimi, 2018 [11]); (Pandian, Krishnan and Kumar, 2018 [31]); (Ramamurthy and Mg, 2018 [35]); (Gupta, Ariga and Deogade, 2018 [15]); (Vikram et al., 2017 [50]); (Paramasivam, Vijayashree Priyadharsini and Raghunandhakumar, 2020 [32]); (Palati et al., 2020 [30]); (Samuel, Acharya and Rao, 2020 [40]). Now the growing trend in this area motivated us to pursue this project

This study is done to determine the prevalence of alveoloplasty done among complete denture patients.

\section{Materials and Methods}

\section{Study design and study setting:}

The study is the retrospective study. Information regarding the patient's treatment was collected from patients' case sheet records.

\section{Participants:}

All patients who have undergone complete denture treatment and patients who have undergone alveoloplasty from the Department of prosthodontics and Department oral and maxillofacial urgent were added to the study.

\section{Ethical approval:}

The ethical approval for the research (SDC/SIHEC/2020/DIASDATA/0619-0320) was issued by the ethical committee of Saveetha Dental college, Saveetha Institute of medical and Technical science, Saveetha University, Chennai

\section{Study size:}

Total numbers of patients in the study were 393.

\section{Data Analysis:}

The data was collected from patient reports in hospitals, The obtained data was entered in Microsoft excel 2012 .Then exported to statistical package for social science for windows (version 20.0.SPSS Inc. Chicago III, USA) and all subjected to statistical analysis. Chi square test was employed with a level of significance set at $\mathrm{P} 0.05$.

\section{Results}

In our present study figure 1 shows frequency of alveoloplasty in complete denture patients. Patients who have not done alveoloplasty accounted for 353 which is $89.9 \%$, Patients who have undergone alveoloplasty procedure accounted for 39 which was $9.9 \%$.Figure 2 shows the association between alveoloplasty in complete denture patients and gender. In a total of 393 patients 165 were female patients. In that 146 female patients did not undergo any alveoloplasty and 19 patients underwent alveoloplasty. Total number of male patients were 225 , out of which patients

Figure 1: Frequency bar graph showing patients undergone alveoloplasty procedure. Where, $\mathrm{X}$-axis denotes the alveoloplasty and Y-axis denotes the total number of patients. Patients who have done alveoloplasty (Green) accounts for $9.94 \%$, Patients who have not done alveoloplasty (violet) accounts for $90 \%$.

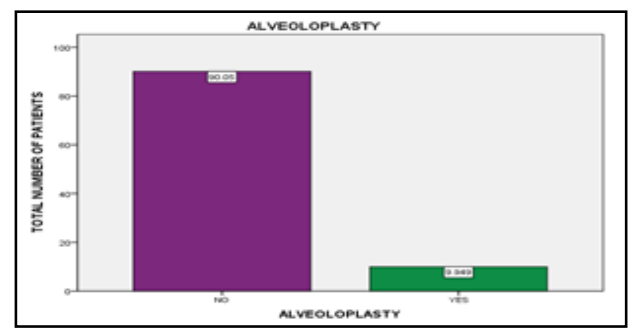

Figure 2: Shows the association between gender and alveoloplasty done. $\mathrm{X}$ axis represents Gender and $\mathrm{Y}$ - axis represents the number of patients $5.1 \%$ of the males and $4.85 \%$ of the female completely edentulous patients underwent alveoloplasty, however, no statistically significant differences between both the groups were observed.(Pearson Chi square test; $P=0.416, P>0.05$ ).

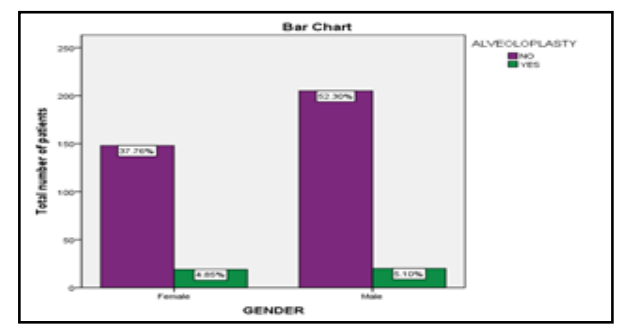


who have undergone alveoloplasty were $20.5 .1 \%$ of the males and $4.85 \%$ of the female completely edentulous patients underwent alveoloplasty, however, no statistically significant differences between both the groups were observed. (Pearson Chi square test; $\mathrm{P}=0.416, \mathrm{P}>0.05)$.

\section{Discussion}

The teeth have major role in facial appearance, speech and eating in human life. There are many evidences demonstrating the negative effects of edentulism on the oral health $[17,28]$. Edentulism have a negative influence on oral function, social behaviour and everyday activities. Often there will be a compromised are low self-esteem and fall in the psychosocial wellbeing because of the limitation of the oro facial function of day to day activity $[27,3]$. Edentulous people may restrict themselves from participating in social activities and gathering as they feel embarrassed to smile, speech or eat in from $\backslash$ nt of others, which often makes them isolated $[38,46]$. In such kind of individuals wearing denture could improve their facial and oral appearance. It can also help in improving their facial appearance. It will improve social interactions which may increase their self-esteem and can lead to wellbeing state $[5,20]$.

The pre-prosthetic surgery is done to prepare the mouth before the placement of denture. Some patients require minor oral surgical procedure before receiving a partial or complete denture to ensure maximum level of comfort $[9,6]$. A denture sits on the bone ridge so, it is very important that the bone is proper shape and size. Procedure for preparing include bone smoothing, reshaping, removal of excess bone and gum tissue excess removal $[8,1]$. Pre-prosthetic surgery thus serves as an adjunct for the development of a denture foundation that enables fabrication of well fitted and comfortable prosthetics.

Our institution is passionate about high quality evidence based research and has excelled in various fields (Pc, Marimuthu and Devadoss, 2018 [33]; Ramesh et al., 2018 [36]; Vijayashree Priyadharsini, Smiline Girija and Paramasivam, 2018 [49]; Ezhilarasan, Apoorva and Ashok Vardhan, 2019 [12]; Ramadurai et al., 2019 [34]; Sridharan et al., 2019 [42]; Vijayashree Priyadharsini, 2019 [48]; Chandrasekar et al., 2020 [7]; Mathew et al., 2020 [26]; R et al., 2020 [37]; Samuel, 2021 [39]). We hope this study adds to this rich legacy.

\section{Conclusion}

With the limitation of our study, Patients who underwent alveoloplasty before receiving complete denture were found to be minimal. Alveoloplasty should be mandated in suitable situations to ensure better health of complete denture patients and eventually to improve comfort and success rate.

\section{References}

[1]. Ajay R, Suma K, Ali SA, Kumar Sivakumar JS, Rakshagan V, Devaki V, Divya K. Effect of Surface Modifications on the Retention of Cement-retained Implant Crowns under Fatigue Loads: An In vitro Study. J Pharm Bioallied Sci. 2017 Nov;9(Suppl 1):S154-S160. Pubmed PMID: 29284956.

[2]. Ashok V, Ganapathy D. A geometrical method to classify face forms. J Oral Biol Craniofac Res. 2019 Jul-Sep;9(3):232-235. Pubmed PMID: 31198677.

[3]. Ashok V, Suvitha S. Awareness of all ceramic restoration in rural population. Res J Pharm Technol. 2016;9(10):1691-3.
[4]. Asma P, Mamoona A M, M Azhar S. Incidence of alveoloplasty and its indications-protocol to reduce the incidence. 2013.

[5]. Awad MA, Locker D, Korner-Bitensky N, Feine JS. Measuring the effect of intra-oral implant rehabilitation on health-related quality of life in a randomized controlled clinical trial. J Dent Res. 2000 Sep;79(9):1659-63. Pubmed PMID: 11023260.

[6]. Basha FY, Ganapathy D, Venugopalan S. Oral hygiene status among pregnant women. Res J Pharm Technol. 2018;11(7):3099-102.

[7]. Chandrasekar R, Chandrasekhar S, Sundari KKS, Ravi P. Development and validation of a formula for objective assessment of cervical vertebral bone age. Prog Orthod. 2020 Oct 12;21(1):38. Pubmed PMID: 33043408.

[8]. Chari H, Shaik KV. Preprosthetic surgery: review of literature. IJSS Case Reports \& Reviews. 2016 Sep;3(4):10.

[9]. Choudhari S, Rakshagan V, Jain AR. Evolution in preprosthetic surgery current trends: A review. Drug Invention Today. 2018 Oct 1;10(10).

[10]. Devaki VN, Balu K, Ramesh SB, Arvind RJ, Venkatesan. Pre-prosthetic surgery: Mandible. J Pharm Bioallied Sci. 2012 Aug;4(Suppl 2):S414-6. Pubmed PMID: 23066301.

[11]. Ezhilarasan D. Oxidative stress is bane in chronic liver diseases: Clinical and experimental perspective. Arab J Gastroenterol. 2018 Jun;19(2):56-64. Pubmed PMID: 29853428.

[12]. Ezhilarasan D, Apoorva VS, Ashok Vardhan N. Syzygium cumini extract induced reactive oxygen species-mediated apoptosis in human oral squamous carcinoma cells. J Oral Pathol Med. 2019 Feb;48(2):115-121. Pubmed PMID: 30451321.

[13]. Ezhilarasan D, Sokal E, Najimi M. Hepatic fibrosis: It is time to go with hepatic stellate cell-specific therapeutic targets. Hepatobiliary Pancreat Dis Int. 2018 Jun;17(3):192-197. Pubmed PMID: 29709350.

[14]. Ganapathy D, Sathyamoorthy A, Ranganathan H, Murthykumar K. Effect of Resin Bonded Luting Agents Influencing Marginal Discrepancy in All Ceramic Complete Veneer Crowns. J Clin Diagn Res. 2016 Dec;10(12):ZC67ZC70. Pubmed PMID: 28209008.

[15]. Gupta P, Ariga P, Deogade SC. Effect of Monopoly-coating Agent on the Surface Roughness of a Tissue Conditioner Subjected to Cleansing and Disinfection: A Contact Profilometric In vitro Study. Contemp Clin Dent. 2018 Jun;9(Suppl 1):S122-S126. Pubmed PMID: 29962776.

[16]. Hillerup S. Preprosthetic surgery in the elderly. J Prosthet Dent. 1994 Nov;72(5):551-8. Pubmed PMID: 7844760.

[17]. Hugo FN, Hilgert JB, de Sousa Mda L, Cury JA. Oral status and its association with general quality of life in older independent-living south-Brazilians. Community Dent Oral Epidemiol. 2009 Jun;37(3):231-40. Pubmed PMID: 19302576

[18]. Jain AR. Prevalence of partial edentulousness and treatment needs in rural population of South India. World J Dent. 2017 Jun;8(3):213-7.

[19]. Jain AR, Nallaswamy D, Ariga P, Ganapathy DM. Determination of correlation of width of maxillary anterior teeth using extraoral and intraoral factors in Indian population: A systematic review. World J Dent. 2018 Jan;9(1):6875.

[20]. Jones JA, Orner MB, Spiro A 3rd, Kressin NR. Tooth loss and dentures: patients' perspectives. Int Dent J. 2003;53(5 Suppl):327-34. Pubmed PMID: 14562938.

[21]. Jyothi S, Robin PK, Ganapathy D. Periodontal health status of three different groups wearing temporary partial denture. Res J Pharm Technol. 2017;10(12):4339-42.

[22]. Ke Y, Al Aboody MS, Alturaiki W, Alsagaby SA, Alfaiz FA, et al. Photosynthesized gold nanoparticles from Catharanthus roseus induces caspasemediated apoptosis in cervical cancer cells (HeLa). Artif Cells Nanomed Biotechnol. 2019 Dec;47(1):1938-1946. Pubmed PMID: 31099261.

[23]. Krishnan RP, Ramani P, Sherlin HJ, Sukumaran G, Ramasubramanian A, Jayaraj G, Don KR, Santhanam A. Surgical Specimen Handover from Operation Theater to Laboratory: A Survey. Ann Maxillofac Surg. 2018 JulDec;8(2):234-238. Pubmed PMID: 30693238.

[24]. Lawson WA. Objectives of pre-prosthetic surgery. Br J Oral Surg. 1972 Nov;10(2):175-88. doi: $10.1016 / \mathrm{s} 0007-117 \times(72) 80034-9$. PMID: 4568062.

[25]. MacEntee MI, Glick N, Stolar E. Age, gender, dentures and oral mucosal disorders. Oral Dis. 1998 Mar;4(1):32-6. Pubmed PMID: 9655042.

[26]. Mathew MG, Samuel SR, Soni AJ, Roopa KB. Evaluation of adhesion of Streptococcus mutans, plaque accumulation on zirconia and stainless steel crowns, and surrounding gingival inflammation in primary molars: randomized controlled trial. Clin Oral Investig. 2020 Sep;24(9):3275-3280. Pubmed PMID: 31955271.

[27]. Naik AV, Pai RC. Study of emotional effects of tooth loss in an aging north Indian community. ISRN Dent. 2011;2011:395498. Pubmed PMID: 22203909.

[28]. Nitschke I, Müller F. The impact of oral health on the quality of life in the elderly. Oral health \& preventive dentistry. 2004 Jan 1;2:271-5. 
[29]. Padavala S, Sukumaran G. Molar Incisor Hypomineralization and Its Prevalence. Contemp Clin Dent. 2018 Sep;9(Suppl 2):S246-S250. Pubmed PMID: 30294152.

[30]. Palati S, Ramani P, Shrelin HJ, Sukumaran G, Ramasubramanian A, Don KR, Jayaraj G, Santhanam A. Knowledge, Attitude and practice survey on the perspective of oral lesions and dental health in geriatric patients residing in old age homes. Indian J Dent Res. 2020 Jan-Feb;31(1):22-25. Pubmed PMID: 32246676

[31]. Pandian KS, Krishnan S, Kumar SA. Angular photogrammetric analysis of the soft-tissue facial profile of Indian adults. Indian J Dent Res. $2018 \mathrm{Mar}$ Apr;29(2):137-143. Pubmed PMID: 29652003.

[32]. Paramasivam A, Vijayashree Priyadharsini J, Raghunandhakumar S. N6adenosine methylation (m6A): a promising new molecular target in hypertension and cardiovascular diseases. Hypertens Res. 2020 Feb;43(2):153154. Pubmed PMID: 31578458.

[33]. J PC, Marimuthu T, C K, Devadoss P, Kumar SM. Prevalence and measurement of anterior loop of the mandibular canal using CBCT: A cross sectional study. Clin Implant Dent Relat Res. 2018 Aug;20(4):531-534. Pubmed PMID: 29624863.

[34]. Ramadurai N, Gurunathan D, Samuel AV, Subramanian E, Rodrigues SJL. Effectiveness of $2 \%$ Articaine as an anesthetic agent in children: randomized controlled trial. Clin Oral Investig. 2019 Sep;23(9):3543-3550. Pubmed PMID: 30552590

[35]. Ramamurthy JA, Mg V. Comparison of effect of Hiora mouthwash versus Chlorhexidine mouthwash in gingivitis patients: A clinical trial. Asian J Pharm Clin Res. 2018 Jul 7;11(7):84-8.

[36]. Ramesh A, Varghese S, Jayakumar ND, Malaiappan S. Comparative estimation of sulfiredoxin levels between chronic periodontitis and healthy patients - A case-control study. J Periodontol. 2018 Oct;89(10):1241-1248. Pubmed PMID: 30044495.

[37]. R H, Ramani P, Ramanathan A, R JM, S G, Ramasubramanian A, K M. CYP2 C9 polymorphism among patients with oral squamous cell carcinoma and its role in altering the metabolism of benzo[a]pyrene. Oral Surg Oral Med Oral Pathol Oral Radiol. 2020 Sep;130(3):306-312. Pubmed PMID: 32773350 .

[38]. Rodrigues SM, Oliveira AC, Vargas AM, Moreira AN, E Ferreira EF. Implications of edentulism on quality of life among elderly. Int J Environ Res Public Health. 2012 Jan;9(1):100-9. Pubmed PMID: 22470281.

[39]. Samuel SR. Can 5-year-olds sensibly self-report the impact of develop- mental enamel defects on their quality of life? Int J Paediatr Dent. 2021 Mar;31(2):285-286. Pubmed PMID: 32416620.

[40]. Samuel SR, Acharya S, Rao JC. School Interventions-based Prevention of Early-Childhood Caries among 3-5-year-old children from very low socioeconomic status: Two-year randomized trial. J Public Health Dent. 2020 Jan;80(1):51-60. Pubmed PMID: 31710096.

[41]. Selvan SR, Ganapathy D. Efficacy of fifth generation cephalosporins against methicillin-resistant Staphylococcus aureus-A review. Res J Pharm Technol. 2016;9(10):1815-8.

[42]. Sridharan G, Ramani P, Patankar S, Vijayaraghavan R. Evaluation of salivary metabolomics in oral leukoplakia and oral squamous cell carcinoma. J Oral Pathol Med. 2019 Apr;48(4):299-306. Pubmed PMID: 30714209.

[43]. Subasree S, Murthykumar K. Effect of aloe vera in oral health-A review. Res J Pharm Technol. 2016;9(5):609-12.

[44]. Taylor RL. A chronological review--1960-1985 of the changing concepts related to modifications, treatment, preservation and augmentation of the complete denture basal seat. Aust Prosthodont Soc Bull. 1986 Dec;16:1739. PMID: 3527231.

[45]. Varghese SS, Ramesh A, Veeraiyan DN. Blended Module-Based Teaching in Biostatistics and Research Methodology: A Retrospective Study with Postgraduate Dental Students. J Dent Educ. 2019 Apr;83(4):445-450. Pubmed PMID: 30745352

[46]. Venugopalan S, Ariga P, Aggarwal P, Viswanath A. Magnetically retained silicone facial prosthesis. Niger J Clin Pract. 2014 Mar-Apr;17(2):260-4. Pubmed PMID: 24553044.

[47]. Vijayalakshmi B, Ganapathy D. Medical management of cellulitis. Research Journal of Pharmacy and Technology. 2016;9(11):2067-70.

[48]. Vijayashree Priyadharsini J. In silico validation of the non-antibiotic drugs acetaminophen and ibuprofen as antibacterial agents against red complex pathogens. J Periodontol. 2019 Dec;90(12):1441-1448. Pubmed PMID: 31257588.

[49]. Vijayashree Priyadharsini J, Smiline Girija AS, Paramasivam A. In silico analysis of virulence genes in an emerging dental pathogen A. baumannii and related species. Arch Oral Biol. 2018 Oct;94:93-98. Pubmed PMID: 30015217.

[50]. Vikram NR, Prabhakar R, Kumar SA, Karthikeyan MK, Saravanan R. Ball Headed Mini Implant. J Clin Diagn Res. 2017 Jan;11(1):ZL02-ZL03. Pubmed PMID: 28274084. 